\title{
Landowner and Land Trust Agent Preferences for Conservation Easements: Implications for Sustainable Land Uses and Landscapes
}

\author{
CHRISTOPHER T. BASTIAN* \\ Department of Agricultural and Applied Economics, University of Wyoming. \\ E-mail: *bastian@uwyo.edu \\ CATHERINE M.H. KESKE \\ Division of Social Science, Memorial University of Newfoundland. \\ E-mail: ckeske@grenfell.mun.ca \\ DONALD M. McLEOD \\ Department of Agricultural and Applied Economics, University of Wyoming. \\ E-mail: $\underline{\text { dmcleod@uwyo.edu }}$ \\ DANA L. HOAG \\ Department of Agricultural and Resource Economics, Colorado State University. \\ E-mail: dana.hoag@ colostate.edu
}

*Corresponding author - Contact Information.

Christopher T. Bastian

Dept. of Ag. \& Appl. Econ.

University of Wyoming

1000 E. University Avenue, Dept. 3354

Laramie, WY 82071

Ph. 1-307-766-4377

Fax 1-307-766-5544

e-mail: bastian@uwyo.edu 


\section{$1 \quad$ Abstract}

2 Conservation easements offer sustainable land use and environmental conservation through land

3 use restrictions. Opportunities exist to improve the efficiency by which parties interested in

4 conservation easement transactions are matched, which may contribute to the overall protection

5 of agricultural landscapes. This study utilizes stated choice questions to elicit preferences for

6 conservation easements by both landowners, as potential easement suppliers, and land trust

7 professionals as potential easement demanders. A random utility model is estimated for

8 landowners and for land trust professionals. Results indicate both preference overlap and

9 preference divergence between these two sets of respondents. Significant opportunities exist to

10 reduce search and transactions costs, improve easement acceptance, and increase environmental

11 protection via increased transaction frequency of conservation easements in this emerging

12 market. When negotiating with landowners, land trusts need to be aware of concerns related to

13 issues such as managerial control, public access, lack of trust, and financial compensation.

14 Moreover, heterogeneity amongst participants regarding these issues suggests some agricultural 15 landowners may be more or less concerned about these issues. 
Sustainable land use and environmental conservation of agricultural lands can be achieved through various public and private policies, such as conservation easements (CE). Since agricultural lands have generally improved in the provision of environmental services over time (Moss \& Schmitz, 2014), understanding how CEs may be used to keep agricultural lands from conversion could contribute to sustainable agricultural landscapes. Generally defined, CEs are a market-based tool used to protect environmental amenities and ecosystem services that arise on private lands (Bergstrom, Dillman, \& Stoll, 1985; Polasky, Johnson, Keeler, Kovacs, Nelson,

24 Pennington, Plantinga, \& Withey, 2012). For example, CE agreements often yield economic 25 incentives to agricultural landowners for social benefits provided by their land such as open space, wildlife habitat, and cultural ecosystem services like sense of place (Bergstrom, Dillman,

27 \& Stoll, 1985; Cross, Keske, Lacy, Hoag, \& Bastian, 2011; Duke \& Lynch, 2006; Lynch \& 28 Lovell, 2003; Magnan, Seidl, \& Loomis, 2012; Merenlender, Huntsinger, Guthey, \& Fairfax, 2004; Rissman \& Sayre, 2012). CEs may also be enacted to buffer agricultural lands from encroaching residential or industrial land uses and to ensure the availability of agricultural production (Green \& Stager, 2002; Inman \& McLeod, 2002; Inman, McLeod, \& Menkhaus, 2002; Lubowski, Plantinga, \& Stavins, 2008; Milder \& Clark, 2012).

The use of CEs increased four-fold since 2000 (Chang, 2011). During this time the literature blossomed with studies that evaluate the economic efficiency and expenditures of CE transactions (Bode, Probert, Turner, Wilson, \& Venter, 2011; Duke, Dundas, \& Messer, 2013; Lerner, Mackey, \& Casey, 2007; Milder \& Clark, 2012); how effectively the agreements meet 37 conservation targets (Milder, Lassoie, \& Bedford, 2008; Rissman, Lozier, Comendant, Karevia, 38 Kiesecker, Shaw, \& Merenlender, 2007); and both landowner (see for example Farmer, 
Chancellor, \& Fischer, 2011) and land trust motivations for entering into CE agreements (see for

40 example Cropper, McLeod, Bastian, Keske, Hoag, \& Cross, 2012). There is a paucity of

41 research directly comparing landowner (CE suppliers) and land trust (CE demanders)

42 motivations for entering into easements, however.

This study contributes to the sustainable landscape and land use literature by using a

44 stated choice survey and random utility model analysis to assess both landowner and land trust

45 preferences for CE attributes within the western United States. By analyzing both the landowner

46 "supply" side and the land trust "demand" side of the market utilizing the same stated choice

47 scenarios, insight is provided into attributes that may influence CE negotiations for agricultural

48 lands. Achieving an understanding of potential attributes/conditions that may affect a landowner

49 or land trust agent's decision entering into a CE agreement could improve the likelihood of CE

50 implementation and CE market efficiency overall. Determining CE attributes and incentives that

51 lead to successful land conservation objectives can also facilitate the sustainable use of rural

52 parcels.

The following background section provides further explanation of CEs, a summary of

54 findings regarding landowner and land trust motivations for entering into easements, and a

55 discussion of associated market issues for CEs.

\section{Background}

A CE is a voluntary, but legally binding, agreement where the landowner commits to

58 limit residential development and/or future changes in land use, thereby preserving socially

59 desired amenities. CEs are most frequently used in North America, but similar policies have

60 been implemented throughout the world. Landowners may sell a CE, donate a CE to receive tax

61 benefits, or receive a combination of the two. It is common for landowners entering into CEs to 
62 agree to the following: (1) prohibit future building on the parcel; (2) limit future buildings to

63 certain areas on the parcel; and/or (3) restrict land use for which they may receive payment

64 and/or tax benefits. Land under CE remains privately owned and can be transferred, although

65 the agreed upon development rights are effectively "extinguished” (Gustanski \& Squires, 2000).

66 Throughout the rest of the paper, the market for CEs refers to transactions negotiated by or

67 between agricultural landowners (as potential suppliers) and land trusts (as potential demanders). Landowners who supply agricultural lands, may approach conservation organizationsmost commonly land trusts_- to engage in CEs that will protect the land. Likewise, land trusts

70 also actively seek out landowners or specific parcels for CE transactions. A land trust is defined

71 as a U.S. Internal Revenue Service 501(c)(3) organization whose mission specifically involves

72 CE acquisition or stewardship (Land Trust Alliance, 2015). Land trusts represent the "demand 73 side" of the CE market for the purposes of this study. The market for CEs then is based on the 74 desired attributes and preference motivations of demanders and suppliers.

\subsection{Landowner motivations for supplying conservation easements}

Place attachment, protecting the environment or wildlife habitat, and financial incentives,

77 including both payment and/or estate tax benefit, are consistently found to be motivations in the

78 literature for landowners placing or considering the placement of easements on their land (Brain,

79 Hostetler, \& Irani, 2014; Cross et al., 2011; Farmer, Knapp, Meretsky, Chancellor, \& Fischer,

80 2011; Farmer, Chancellor, \& Fischer, 2011; Miller, Bastian, McLeod, Keske, and Hoag, 2011).

81 However, the relative importance of financial incentives seems to vary in the literature. This

82 may be, in part, related to the importance of the land in providing a livelihood for the landowner.

83 Cross et al. (2011) conclude economic dependence on the land negatively affects easement

84 adoption. Furthermore, Farmer, Meretsky, Knapp, Chancellor, and Fischer (2015) find that those 
85 receiving monetary benefits from the land were less likely to place an easement without

86 significant benefits for doing so, but absentee landowners did not weight financial incentives as

87 heavily in choosing an easement. Access to institutions enabling conservation easements and the

88 potential for tradeable tax permits to capture easement benefits also have been attributed to

89 increased frequency of easement transactions (McGaffin, McLeod, Bastian, Hoag, \& Hoag,

90 2012). Concerns over development pressure and protecting land for society or the public good

91 also surface as important motivators for landowners placing easements (Farmer, Knapp,

92 Meretsky, Chancellor \& Fischer, 2011; Farmer, Chancellor \& Fischer, 2011). Other variables

93 found to be positively related to interest in easements include belonging to environmental

94 organizations, recreational land-use, gathering wild food, and land entitlement (Brenner,

95 Lavallato, Cherry, \& Hileman, 2013).

Positive relationships with land trusts comes out as an important dimension impacting

97 easement choice and overall satisfaction of placing an easement in the literature. Rissman and

98 Sayre (2012) study conservation easement agreements and interview both land trust and

99 landowners in two ranchlands areas. They conclude that relations between landowners and

100 easement holders affect both complexity of agreements and satisfaction associated with easement

101 choice. Stroman and Kreuter (2014) conclude that frequency of contact between landowners and

102 easement holders and the type of agency or organization (federal, state, local or non-

103 governmental agency) holding the easement significantly affected the level of landowner

104 satisfaction with the easement and perceived relationship with the easement holder. Brain,

105 Hostetler, and Irani (2014) find Florida cattle ranchers were more likely to enter into a

106 conservation easement (CE) agreement if they had a positive attitude about CE outcomes, felt 
107 influential others would be supportive of CEs, and indicated higher trust in conservation

108 organizations.

Several issues emerge in the literature that adversely affect landowner acceptance of

110 easements. Easements in perpetuity and the potential for outside influence on managerial

111 decisions negatively impact landowners' attitudes about easement choice (Miller et al., 2011;

112 Sorice et al., 2013). Sorice et al. (2013) conclude highly controlling programs, permanent

113 conservation easements, and programs that put landowners at risk for future regulation reduced

114 landowner participation. The authors indicate that greater levels of compensation and landowner

115 autonomy to make land management decisions could increase participation in conservation

116 programs. The requirement of public access also may detract from placing an easement (Miller et

117 al., 2011). Concerns over liability and negative impacts on agricultural activities likely explain

118 much of the undesirability of this attribute (Miller et al., 2011). Overall, the literature seems to

119 suggest that specific easement attributes, conservation values, respondent characteristics, positive

120 land trust relationships, and financial incentives impact the willingness to supply CEs.

\subsection{Land trust motivations for entering into conservation easements}

122 Research indicates that conservation values and preserving sense of place often motivate

123 land trusts to enter into conservation easements. Keske (2008) identifies protection of habitat,

124 biodiversity, natural areas, ecosystems, prime agricultural lands, proximity to other protected

125 lands, historic lands, public access, nature based recreation scenic beauty, open space, cultural

126 uses, hunting rights, educational opportunities and water conservation as being important to land

127 trust agents when considering conservation easements. Keske (2008) asserts these conservation

128 values are often part of a larger goal or objective to preserve sense of place. Rissman (2010)

129 states that increased agreement complexity and specification over time came about due to 
130 potential concerns over inflexibility in changing original easement agreements and to address 131 more specific conservation goals.

Other dimensions affecting land trust motivations include aspects that may impact public

133 acceptance of conservation easements and related support of land trust activity. Lieberknect

134 (2009) determines from a national survey of land trust executives that $78 \%$ of land trusts allow

135 public access to some or all of their lands and view this as an important way to improve support

136 for their conservation efforts. Gerber and Rissman (2012) find the Nature Conservancy prefers

137 obtaining of properties or property rights over engaging in land-use planning as such acquisitions

138 are viewed as voluntary.

While the literature seems to indicate some consistent factors impacting land trust

140 motivations, other research suggests that preference heterogeneity across land trusts likely affects

141 conservation easement transactions. Cropper et al. (2012) segment land trust agents by sense of

142 place scores and preferences for providing ecosystem services and find different weightings of

143 factors affecting easement choice. Those land trust respondents ranking high on provision of

144 ecosystem services weighted provision of public access on easements, increased benefits paid to

145 landowners, and concerns regarding local development growth pressure as negatively impacting

146 placement of an easement. The results for that segment ranked having control over agricultural

147 practices, and provision of wildlife habitat as positively impacting easement choice. The results

148 for the segment ranking low in sense of place scores indicated wildlife habitat, and managerial

149 control positively impacted easement choice, but benefits paid to landowners and public access

150 were not significant in explaining easement choice. Results for all land trust segments indicated

151 easements in perpetuity positively impacted easement choice. Overall, the literature suggests that

152 mutual interests overlap at times, but that there is also potential divergence, between landowner 
153 and land trust agent preferences when entering into conservation easements. Thus, our proposed

154 study that directly compares these supply and demand motivations should further illuminate

155 potential issues and improvements for conservation easement transactions.

156

157

158

159

160

161

162

163

164

165

166

167

168

169

170

171

172

173

174

\subsection{Market considerations for conservation easement transactions}

While preferences ultimately impact both suppliers' and demanders' motivations for entering into an easement, other economic issues may well affect easement transactions too. High transaction and search costs (i.e., the more it costs to develop and come to an agreement, and the harder it is to find a party interested in the same type of easement attributes) can ultimately cause market failure (Davidson \& Weersink, 1998). The increase in transactions over the past decade suggests that the market is evolving towards efficiency (i.e., the most and best parcels under easement for the least cost) (Keske, Hoag, \& Bastian, 2009). However, inconsistent price or benefit signals in the CE market (Anderson \& Weinhold, 2008; Geoghegan, Lynch, \& Bucholtz, 2003) and in CE appraisals (Boykin \& McLaughlin, 2006; Keske, 2008) are strong indicators that market inefficiency continues (Keske, Hoag, \& Bastian, 2009). Hence, changes to improve both the number and quality of easements (efficiency) and to reduce both search and transaction costs could lead to practical and lasting impacts to how conservation land is acquired through CEs. Achieving an understanding of land trust and landowner preferences for easement attributes could, at least in theory, improve opportunities for landowners and land trusts to successfully negotiate an agreeable CE. This could increase the number and quality of CEs resulting in an increase in acreage under CE protection at a more efficient market value, thereby improving overall market efficiency.

\section{Methodology}


Our overall research objective is to compare preferences of landowners and land trust

176

177

178

179

180

181

182

183

184

185 agents regarding conservation easements. We do this by conducting stated choice surveys and random utility model analyses across samples of agricultural landowners and land trust agents in the intermountain west.

\subsection{Data Collection}

\subsubsection{Questionnaire}

Contracts for CEs are often negotiated privately in order to maintain landowner confidentiality for sensitive information such as annual income (Keske, 2008). As a result, landowner preferences may not be directly observed, and socio-economic data may not be readily available. Thus, for the purposes of this study, stated choice questions are used to obtain preferences for the CEs (Louviere, Hensher \& Swait, 2000), as well as socio-economic data.

The stated choice questionnaires were developed from a qualitative research phase that consisted of semi-structured interviews of landowners and land trusts during 2005 and 2006. Interested readers may consult Keske (2008) and Keske et al. (2011) for specifics about qualitative research results from the land trust interviews and Miller et al. (2011) for results from the landowner focus groups.

The stated choice portion of the questionnaires was developed from analyses of the landowner and land trust agent focus group interviews. Five CE attributes were identified for inclusion in the stated choice questions. These five attributes were: 1) Easement length or duration; 2) Public access; 3) Inclusion of wildlife habitat; 4) Restricted managerial control of landowner by land trusts; and, 5) Financial benefit provided to landowner in exchange for the

CE. These qualitative findings regarding important $\mathrm{CE}$ attributes to both landowners and land trust agents led to the development of two (demander and supplier) parallel questionnaires. 
The five CE attributes, identified previously, were represented in twenty-four choice set

pairs with varying levels of attributes. The literature suggests respondents are able to judge and compare alternatives across repeated choices, but increased complexity, number of attributes, altering order of attributes, and large numbers of attribute levels can affect respondent burden and preference weightings (Thurstone, 1927; Louviere, Hensher \& Swait, 2000; DeShazo and Fermo, 2002; Day, Bateman, Carson, Dupont, Louviere, Morimoto, Scarpa, \& Wang, 2012). For these reasons we used relatively simple, realistic levels for our five $\mathrm{CE}$ attributes (Easement length -2 levels; Public access -2 levels; Inclusion of wildlife habitat - 2 levels; Restricted managerial control - 2 levels; and, Financial benefit -5 levels). We used a computer generated design that maximized a D-efficiency criterion in order to have the least number of choice pairs with the greatest chance of minimizing the variance and covariance of the parameter estimates (see Kuhfeld, Tobias \& Garratt, 1994). This design was determined using the Optex procedure in SAS (1990) and had a diagonal efficiency equaling 95\%. Survey participants were tasked with answering multiple stated choice questions (two for landowner surveys and four for land trust agent surveys). The questionnaires contained the same stated choice question design for both the landowners and land trust professionals. Twelve versions of the questionnaire were developed for landowners, using two stated choice questions each (for example, version 1 used choice sets 1 and 2, version 2 used choice sets 3 and 4, etc.). These twelve versions were mailed to an equal number of potential respondents in the sample. Six versions of the survey, containing four choice questions each (version 1 - choice sets 1 through 4 , version 2 - choice sets 5-8, etc.) were developed for the land trust professionals, and again each version was equally distributed across potential respondents. A larger number of stated choice questions (four instead of two) appeared on the land trust surveys in order to obtain sufficient responses across the stated choice 
221 questions. Louviere, Hensher and Swait (2000) indicate that respondents have analyzed up to 32

222 choice profiles successfully. Day et al. (2012) analyze responses from 17 stated choices per

223 respondent and conclude no fatigue effects were present. We believe our design should provide

224 stable preference weighting results across respondents. The sections that follow provide

225 summarization of the respective supplier and demander questionnaires.

226 The landowner questionnaire had four parts. Part A presented Likert scale questions

227 regarding knowledge and attitudes about land use and conservation in their area. This section

228 included questions regarding different dimensions of community attachment or "sense of place"

$229-a$ cultural ecosystem service and multi-dimensional concept involving emotional attachment,

230 satisfaction, and identity (Hummon, 1992; Jorgensen \& Stedman., 2001). Part B asked

231 respondents about the best estimate of what their land would sell for on the market (average price

232 per acre), characteristics of their land using Likert scale questions, a description of land use on

233 percentage of their deeded acres, and whether their lands bordered a subdivision, had a CE on it

234 or bordered lands with a CE. Part C asked our stated choice questions, and questions regarding

235 their views about CEs and conservation organizations. Part D of the survey asked questions

236 about demographic characteristics of respondents.

237 The land trust agent questionnaire had five parts. Part A asked respondents about their

238 organization's use of CEs. Part B asked respondents about their attitudes and those of their

239 organization regarding land use and conservation in their area including questions about different

240 dimensions of community attachment or sense of place. Part C asked respondents about their

241 estimates of the average market price per acre for lands in the area and attitude questions about

242 obstacles to conserving lands in their area. Part D asked stated choice questions regarding 
243 conservation easements, and Part E asked demographic information about the respondents and

244 about their organization (such as number of employees and operating budget).

Whenever possible, the survey was identical for landowners and land trusts, with minimal

246 variation in question phrasing. For example, the landowner survey had the following statement

247 regarding the importance of conserving nature on their land followed by a Likert scale indicating

248 their level of agreement: "I have a responsibility to conserve nature (wildlife, open space) on my

249 land." The related land trust agent survey question was worded as follows: "Our organization

250 has a responsibility to conserve natural amenities (wildlife, open space)." The section for the

251 stated choice questions in the landowner questionnaire indicated we were trying to understand

252 their perspectives on conservation easements and included a definition of a conservation

253 easement. Prior to the stated choice question involving the appropriate stated choice pair (see

254 example in Figure 1) the following statement was made: "Assume you are negotiating with an

255 organization to place a conservation easement on a parcel (i.e., this can be a portion) of the land

256 that you own or manage. Indicate which easement you would choose below. (Check the most

257 appropriate answer)." The land trust agent questionnaire indicated we wanted to understand

258 their preferences for conservation easements from the perspective of a land trust and then stated

259 the following just prior to the stated choice pairs (see example in Figure 1): "Assume you are

260 negotiating with a landowner to place a conservation easement on a parcel. Please complete the

261 following four scenarios and carefully review the following conservation easement choices,

262 which have been described by five features. Given the description of each, please determine

263 which features you would choose when negotiating an easement and check the appropriate box." 
The Wyoming and the Colorado Agricultural Statistics Service offices provided a random

267 sample of agricultural producers in Wyoming and Colorado, stratified by agricultural sales

268 levels. The sample drawn was representative of producers in Wyoming and Colorado as a region

269 based on the latest agricultural census proportions for acres owned and dollars of sales.

270 Producers owning less than fifty acres and/or receiving less than $\$ 1,000$ in agricultural sales

271 annually were not included in the sample. The total sample size was 4,555 potential respondents

272 for the stated choice question versions of the survey. Each version of the survey was mailed to

273 an equal number of potential respondents in the sample.

274 The survey was delivered by the National Agricultural Statistics Service. A modified

275 Dillman (2000) design was employed. Approximately two weeks after the final mailing,

276 approximately 10 percent of the non-respondents were sampled via the telephone. Telephone

277 respondents were asked the entire survey, not a sub-sample of questions. The overall response

278 rate to the survey, including phone respondents, was 46 percent (for a total of 2,101 completed

279 surveys, of which 323 were obtained by phone). Miller (2007) compared respondents to

280 agricultural census statistics and compared phone respondents to mail respondents across

281 demographic variables such as age, education, and gender. It was concluded that the sample was

282 representative of the intended population and that non-response bias was not an issue for the

283 landowner survey.

284

\subsubsection{Land Trust Survey Design, Sample and Response Rate}

Sixty-four prospective land trusts were identified as potentially holding conservation

287 easements in Colorado and Wyoming. These conservation organizations were identified through

288 a review of the 2007 Land Trust Alliance (LTA) member database made available on-line to the 
289 public. The sampling frame ensured basic consistency of conservation easement acquisition and 290 implementation practices as recommended by LTA. In order to increase the sample size and 291 potential number of responses across all six versions of the survey, another 35 land trusts in the 292 intermountain West (ID, UT, MT, and NM) also were approached for study participation. Those 293 land trusts which held conservation easements in Colorado and Wyoming but had headquarters 294 in another intermountain state and an interest in participating in the study were then part of the 295 overall sample. Qualifying organizations included regional and national land trusts, as well as 296 local, state, and national non-profit and governmental organizations. Phone calls were made to 297 the LTA point of contact (usually an executive director) to verify that the organization held 298 conservation easements in the study region, and to inquire about the organization's willingness to 299 participate in the study.

Organizations were queried about the roles of those who were actively engaged with their 301 organization's conservation acquisition process. In the case of small land trusts, sometimes only 302 the executive director made decisions about conservation easement acquisitions. For larger land 303 trusts, multiple staff members and board members were involved in acquiring conservation 304 easements. Hence, the number of surveys distributed to each land trust reflected the number of 305 participants (defined here as "land trust agents") engaged in the conservation easement decision 306 making process.

307 Questionnaires were mailed directly to the point of contact, who distributed them to the 308 other land trust agents. Although the various roles of land trust agents were noted, the names of 309 the participants were not revealed to the researchers or requested on the survey given expressed 310 concerns for anonymity. The surveys were assigned a three digit number, whereby the first 311 number reflected the survey version (1-6). The six versions of the survey were distributed 
312 randomly but evenly across land trusts. Although the three-digit survey numbers were recorded

313 and associated with land trusts in order to track response rates, the surveys did not otherwise

314 contain identifying information that would be associated with individual responses.

315 The survey distribution process followed a modified Dillman design (Dillman, 2000).

316 Participating land trusts received individually prepared survey packets containing a cover letter,

317 written instructions, and questionnaires reflective of the number of land trust agents identified by

318 the point of contact. Questionnaires were returned directly to the Colorado State University

319 Department of Agricultural and Resource Economics through a postage paid stamped envelope.

320 After six weeks, a follow-up phone call was made if less than 50 percent of questionnaires were

321 received from a specific land trust; however, no additional phone calls were made when at least

32250 percent of the surveys were received from that organization. The follow-up phone call

323 ensured that questionnaires were received by the land trust, and the number of land trust agents

324 participating in the study was verified. The actual survey was not conducted by phone during

325 follow-up calls. Approximately one half of the land trusts received a follow-up phone call.

In summary, of the 99 land trusts approached, 89 land trust organizations met the

327 qualifying criteria of holding conservation easements in Colorado and Wyoming. Of these, 74

328 land trusts $(83.15 \%)$ agreed to participate in the study. A total of 417 questionnaires were

329 distributed to land trust agents identified by each conservation organization and there was an

330 overall response rate of $69.8 \%$. The responses were evenly distributed across the six versions of

331 the survey. Further phone follow-up administering the survey might have increased the response

332 rate for land trusts with a response rate between 50\%-100\%. However, it was decided that land

333 trust cooperation and agent anonymity would be better preserved in these situations if no further

334 follow-up occurred, even if the overall response rate was lowered slightly. 
The survey data were analyzed using random utility models as described below.

\subsection{Analysis}

\subsubsection{Random Utility Theory and Model Overview}

In the choice survey, respondents choose between scenarios with differing types and levels of attributes (Figure 1). Thus, variables affecting the respondent's choice to enter into a CE can be obtained or observed and compared across landowners and land trust agents. Choices are depicted using random utility theory assuming that individuals make choices that maximize their utility (i.e., satisfaction gained) on a given choice occasion (Louviere, Hensher \& Swait, 2000). The overriding assumption is that if someone interested in transacting a CE were faced with a choice between $\mathrm{CE}$ alternatives they would choose the $\mathrm{CE}$ that maximizes their utility (satisfaction) at that time. This is represented as follows:

$$
U_{i}=V_{i}+\varepsilon_{i}>U_{j}=V_{j}+\varepsilon_{j}
$$

where the utility function for an individual contains both a deterministic component (measured by observable variables in $V$ ) and an unobservable stochastic component $(\varepsilon)$. Thus, an individual is expected to choose CE alternative $i$ over $\mathrm{CE}$ alternative $j$ for this choice occasion. The researcher measures, in our case, such things as $\mathrm{CE}$ attributes, attitudes toward conservation, and so on (i.e., variables in $V$ ) that may impact utility.

The indirect utility functions identified in equation 1 can be estimated as:

$$
V_{i}=\beta_{k} X_{i}
$$

where $X$ is a vector of $k$ attributes (variables) associated with alternative $i$ and $\beta$ parameters. Thus, when presented with several choices, i.e., easement A (CE A), easement B (CE B) or neither easement, by observing the respondent's choice, the impact of variables potentially affecting that decision can be revealed through statistical analysis of the indirect utility functions 
358 for each potential choice on a given choice occasion using a random utility model (McFadden

359 1976). Estimation of the resulting elasticities demonstrates the sensitivity of choice to model 360 variables.

361 The dependent variable is selected for a given choice occasion: respondents must pick CE

362 “A”, CE "B" or "neither" for each stated choice scenario faced (Figure 1). The probability of 363 choosing CE "A”, CE "B”, or neither (i.e., alternative $i$ ) in a multinomial logit random utility 364 model can be represented as follows:

$$
P_{i: A t}=\frac{e^{V i t}}{\sum_{j=1}^{j} e^{V j t}}
$$

Where $j=$ the number of choice alternatives; $t=$ a given choice occasion; $A=$ the set of available alternatives for choice occasion $\mathrm{t} ; e=$ base of the natural logarithm; and $V=$ is the indirect utility equation as presented earlier. Thus, each random utility model includes $j$ (in our case, three) indirect utility equations to explain $P i$ represented in equation 3.

371 particular variable in the model. The direct elasticity is given by the following equation:

$$
E_{i}=\left(1-P_{i}\right) X_{k i} \beta_{k}
$$

$$
\text { The nonlinearity of the random utility model impacts how elasticities should be }
$$

374 estimated. Thus, the reported elasticities are estimated for each individual observation and then 375 averaged across the observations. This improves accuracy of the elasticity estimates compared 376 to estimating elasticities at the averages of the variables (Louviere, Hensher \& Swait, 2000). The literature suggests that different landowners or land trust agents may weight 378 easement attributes differently in their decision regarding easement choice. This means that each 379 individual might have a different "coefficient" on the easement attribute of interest on a given choice occasion. Thus, if preference heterogeneity exists, a multinomial logit (MNL) model 
381 incorrectly represents the intercept and slope parameters as being homogeneous across

382 respondents (Daniels and Hensher, 2000). For this reason, the model is estimated as a mixed

383 logit formulation where parameters for the easement attributes, found to be statistically

384 significant in an MNL model of choice, are estimated as random parameters while other

385 variables in the model are estimated as non-random parameters. This approach addresses

386 potential serial correlation in the error terms and Independence of Irrelevant Alternative (IIA)

387 violations if the presence of heterogeneity exists (Daniels and Hensher, 2000; Hensher, Rose, \&

388 Greene, 2005). The mixed logit approach tests for dispersion (quantifiable variation of estimates

389 for respondents) around the parameter of interest by simulating different parameters for each

390 observation and estimating a standard deviation parameter associated with each random

391 parameter (Hensher, Rose, \& Greene, 2005). The model is estimated specifying the distributions

392 around the random parameters as normal (others were tested) and one thousand Halton draws are

393 used for the simulated maximum likelihood procedure in LIMDEP using NLOGIT (see Hensher,

394 Rose, \& Greene, 2005). The error terms are i.i.d. extreme value (Hensher \& Greene, 2003).

\subsubsection{Indirect Utility Equations, Variable Descriptions, Expected Signs}

Overall model development was based on past results reported in the literature, our focus

397 group results and economic theory. The model for the landowner, consisting of three indirect

398 utility equations (as per equation 3 for choice probability), is specified as follows:

399

$\mathrm{U}$ ease a,b $=\beta_{1} *$ easement length $+\beta_{2}{ }^{*}$ public access $+\beta_{3}{ }^{*}$ wildlife habitat $+\beta_{4}{ }^{*}$ control +

400

$\beta_{5}{ }^{*}$ benefit $+\beta_{6}{ }^{*}$ state $+\beta_{7} *$ productivity $+\beta_{8} *$ ecosystem $+\beta_{9}{ }^{*}$ community (sense of place) (5)

401

$\mathrm{U}_{\text {neither }}=\operatorname{ascn}+\beta_{10} *$ years $+\beta_{11} *$ college $+\beta_{12} *$ votech $+\beta_{13} *$ graduate $+\beta_{14} *$ agsales +

$402 \beta_{15} *$ offarm $+\beta_{16} *$ Easmentever $+\beta_{17} *$ trust $+\beta_{18} *$ currentlyCE 
The indirect utility equations (5 and 6) for the supply side or landowner model included

404

405

406

407

408

409

410

411

412

413

414

415

416

417

418

419

420

421

422

423

424

425

the following variables for $\mathrm{CE}$ choice (Table 1): length of $\mathrm{CE}$; public access; wildlife habitat included under CE; managerial control; payment as a percent of perceived average market value in addition to any potential tax benefits; state; ag productivity; ecosystem; community. Variable descriptions, descriptive statistics and hypothesized signs of the variables are reported in Table 1.

The indirect utility equation for the "neither" choice (equation 6) included (Table 1):

constant; years; college education; votech training; graduate education; (6); ag sales; off farm;

CE consideration; trust; and, currently easement in place. Please see Table 1 for summary explanations, descriptive statistics, and expected signs of the associated variables in the landowner model.

The land trust model, also consisting of three indirect utility equations, is as follows: $\mathrm{U}_{\text {ease } \mathrm{a}, \mathrm{b}}=\beta_{1}{ }^{*}$ easement length $+\beta_{2} *$ public access $+\beta_{3} *$ wildlife habitat $+\beta_{4} *$ control + $\beta_{5} *$ benefit $+\beta_{6} *$ community (sense of place) $+\beta_{7} *$ ecosystem $+\beta_{8} *$ growth pressure + $\beta_{9} *$ economic attachment

$$
\mathrm{U}_{\text {neither }}=\operatorname{ascn}+\beta_{10} * \text { holdCE }+\beta_{11} * \text { budget }+\beta_{12} * \text { graduate }+\beta_{13} * \text { votech }+\beta_{14} * \text { years }
$$

The indirect utility equations for the demand side or land trust model included the following variables for easement choice (equation 7; Table 2): a vector of CE attributes all with the same wording and attribute levels as described previously for the landowner model - length, public access, wildlife habitat, managerial control and benefit as perceived average per acre value of land in area; community attachment; ecosystem; growth; economic attachment. Table 2 reports descriptions, descriptive statistics and hypothesized signs of the variables.

The indirect utility equation for the "neither" choice (equation 8; Table 2) included the following variables: constant; hold CE; budget; graduate education; votech training; years. 
426 Please see Table 2 for definitions and descriptive statistics of variables used in the land trust

427 model.

428

429

430

431

432

433

434

435

436

437

438

439

440

441

442

443

444

445

446

447 in explaining easement choice. Consistent with a priori expectations from economic theory, the

448 higher the percent of perceived market value of their land for which landowners were 
compensated (Benefit), the more likely landowners were to choose a CE. This variable had a smaller marginal effect than public access or CE length, however.

Model results indicate that the state in which the landowner resided was significant and had the third largest marginal effect of the CE equation variables, suggesting that Wyoming landowners were less likely to choose a CE (Table 3). The more productive the landowner felt his or her land was (Productivity), the less likely he or she was willing to accept a CE scenario. The higher the summated Likert score related to ecosystem service questions or community attachment, the higher the probability the landowner would accept a CE (Table 3).

Considering the estimation for neither CE choice, the higher the level of agricultural product sales the less likely the respondent chose "neither" and conversely more likely chose a CE (Table 3). However, this had a lower marginal effect on probability of choice than some of the other variables. Off-farm employment for the respondent also was negative and significant in explaining the "neither" choice. The longer a landowner had lived in either Colorado or Wyoming (Years), the more likely they were to choose "neither" as their response (Table 3). Post-secondary education, vocational training, or graduate education was not significant in explaining respondent choice. Those who indicated they would not consider placing CEs on their land (Easement Ever) were more likely to choose "neither" and this had the second highest marginal effect, indicating an important weighting in preferences. Those respondents indicating they would trust land trusts to manage the lands under CE (Trust) were less likely to choose neither. This had the highest marginal effect in the "neither" equation. It is interesting to note, however, that only $29 \%$ of the respondents indicated they trusted land trusts (Table 1 ). This suggests the vast majority landowners do not trust land trusts to protect their interests on their property. If the landowner already had a CE in place (Currently CE), they were less likely to 
472 choose "neither", indicating landowners that had some experience with CEs were more likely to 473 consider other CEs on their land.

\subsection{Land Trust Results}

As with the landowner model, the chi-square statistic and a pseudo- $\mathrm{R}^{2}$ measure of 0.235

477 indicates the land trust model is statistically significant in explaining land trust agent choice

478 (Table 3). Interestingly, the mixed logit results do not indicate significant dispersion for any of

479 the easement attributes, suggesting some stability in preference weightings overall across our

480 land trust respondents. Land trust personnel also were more likely to choose a CE that was in

481 perpetuity (Easement Length), and this variable had the highest marginal effect suggesting its

482 relative importance compared to the other variables. This result provides a bit of internal

483 validity, as most policies require the implementation of conservation easements in perpetuity in

484 order for landowners to qualify for financial benefits. Inclusion of wildlife habitat in the CE was

485 positive and significant in explaining a land trust respondent's acceptance of a CE scenario

486 (Table 3). Moreover, this variable had the second highest marginal effect in the land trust model.

487 Potential for land trusts to have input in agricultural operation practices for land under CE

488 (Control) was also positive and significant in explaining acceptance of a CE scenario.

489 The price of the CE (benefit) was negative and significant (Table 3). This is consistent

490 with expectations regarding demand for CEs. If land trust agents perceived that lands in their

491 area with CE potential were considered under growth pressure, respondents were less likely to

492 choose a CE scenario (Table 3). A perception of landowners' economic dependence on their

493 lands was not a determinant to land trust agent CE choice. The respondent's summated Likert

494 score related to their perception that lands in their portfolio provided ecosystem services had no 
495 effect on their CE choice. Interestingly, the composite variable measuring an individual's

496 community attachment was significant in explaining CE choice, suggesting the higher the

497 individual's community attachment score the more likely they chose a CE. Operating budget, in

498 the neither equation, was not significant in land trust professionals' choice of conservation lands.

499 Number of years in the Intermountain West, the current holding of CEs, and whether a

500 respondent reported vocational training were not significant in explaining choice in the model for

501 land trust personnel. The possession of graduate education meant that land trust professionals

502 were less likely to choose "neither." This had one of the larger marginal effects in the model,

503 suggesting education level had a relatively important impact on probability of choice.

504

505

506

5 Discussion and Conclusions

Overall results suggest that landowners and land trusts have some similar preferences (or

507 at least not inconsistent preferences) toward conservation. Both landowners and land trusts were

508 more likely to choose CEs that were in perpetuity and the marginal effects for both models

509 suggest probability of choice is relatively sensitive to this attribute. This result was somewhat

510 unexpected for landowners as both Miller et al. (2011) and Sorice et al. (2013) indicate concerns

511 with permanent conservation easements. However, the mixed logit formulation does indicate

512 significant dispersion for this parameter, likely indicating a wide range of preferences related to

513 this attribute. The basis for this overall finding may be linked to policies related to the financial

514 benefits associated with CEs. Conservation easements must be in perpetuity in order to qualify

515 for federal tax benefits (IRS §170). It was indicated in the stated choice scenarios that CEs must

516 be in perpetuity to be eligible for tax benefits, in addition to any other remuneration. Our

517 significant dispersion result may well be pointing toward landowners being conflicted about the 
518 tradeoff between perpetuity and potential tax benefits when considering an easement. As land

519 trusts are interested in permanently conserving various attributes, this suggests perpetuity may be

520 less of an issue during CE negotiations than previously thought. However, our results also

521 suggest there is likely heterogeneity amongst landowners related to this attribute.

522 Both landowners and land trust agents were found to be positively motivated by

523 community or place attachment when choosing an easement. This is consistent with the

524 literature for both sides of the market as previous findings suggest both landowners and land

525 trusts seem to feel area lands positively contribute to "place"(Farmer et al., 2011; Cross et al.,

526 2011; Keske, 2008; Keske et al., 2011). Moreover, this finding is consistent with results from

527 the qualitative phase of the study that indicated land trusts are seeking to preserve their

528 community's sense of place (Keske, 2008; Keske et al., 2011). Inclusion of wildlife habitat in

529 the CE had a significantly positive impact on easement choice for land trust agents, but it was

530 insignificant in explaining landowner easement choice. The literature as well our focus group

531 results support the importance of habitat and or biodiversity preservation to land trusts (Keske,

532 2008; Keske et al., 2011). Previous literature as well as our focus group results suggests

533 landowners are often concerned about habitat or nature preservation (Farmer et al., 2011; Miller

534 et al., 2011). Though our model results do not find wildlife habitat as being a significant variable

535 for landowners, it is important to note that for landowners that agreed their land provided

536 important ecosystem services easement acceptance increased. Overall, the literature and our own

537 model results indicate provision of wildlife habitat and conservation of natural amenities are

538 something both CE demanders and suppliers should be able to agree on during negotiations,

539 potentially reducing search costs in this market for this attribute. These results indicate 
540 communication and education regarding the ability to conserve wildlife habitat via CEs could be 541 an important message for land trusts to relay.

Public access had a significant and negative impact on choice in the landowner model.

543 The mixed logit formulation indicates significant heterogeneity may exist among landowners

544 regarding this attribute. Even though it had a negative sign, it was insignificant in the land trust

545 model. These results are consistent with landowner focus group findings overall (Miller et al.,

546 2011). Interestingly, previous research indicates this is often important to land trusts (Keske

547 2008; Liberknect, 2009). However, other research suggests that land trusts may be hesitant to

548 enter into a CE agreement that offers open access, due to concerns about long-term stewardship

549 and conservation issues with publicly accessible property (Boykin \& McLaughlin, 2006).

550 Cropper et al. (2012) conclude those land trusts whose mission focuses more on habitat or

551 biodiversity preservation may find public access as negatively impacting their goals. Overall,

552 these results indicate most of our respondents do not generally want public access as part of a CE

553 transaction. While public access is considered part of the IRS qualifying criteria for a CE, the

554 statistical insignificance to land trusts indicates that public access is not one of the primary

555 deciding factors for implementing a CE across our land trust respondents. This could be related

556 to the overall mission of many land trusts in the study area as being focused on nature

557 preservation. During focus groups (Miller, 2007) many landowners indicated a perception that

558 land trusts often require public access, and the landowner community would likely benefit from

559 the understanding that this is not on the main agenda for many land trusts. Similarly land trusts

560 need to be sensitive to the negative import that access has for landowners in the pursuit of CE

561 transactions. This understanding may open up doors for future CE dialogue. Overall, this 
562 suggests potential for reduced search costs related to either side of this market finding agreement 563 over this attribute.

Our results indicate land trusts generally want to have some control over agricultural

565 operations on CE lands, consistent with our focus group findings (Keske, 2008). This was not a 566 significant factor in the landowner model, however, even though our focus group results as well 567 as previous literature suggest loss of managerial control creates concern (Miller et al., 2011; 568 Sorice et al., 2013). While this finding may be consistent with land trust obligations related to 569 stewardship, these results could be indicative of a potential conflict between landowners and land 570 trusts when negotiating CEs. Landowners were more likely to choose an easement when offered a higher benefit.

572 This is consistent with past research indicating the importance of financial incentives for 573 landowners to enter into conservation easements as well as economic theory (Farmer et al., 2011; 574 Miller et al., 2011). However, some literature has suggested this may be weighted less heavily by 575 some landowners (Farmer et al., 2011). Our results did not indicate significant dispersion on this 576 parameter, suggesting preferences were relatively stable across landowners. Also, as expected 577 from economic theory related to the demand side of this market, results indicate higher offered 578 benefits negatively impacted land trust agents' easement choice. Overall, this indicates 579 consistent price signals and the ability to discover price is important for this market as with any 580 other. This emerging market is characterized by transactions largely negotiated privately, 581 potential information asymmetry and adverse selection related to transacted CEs. Thus, 582 inconsistent price signals could be an important problem causing inefficiency (inappropriate 583 quantities and values of CE transactions) in this market. Moreover, these results coincide with 584 the focus group findings that landowners expect some financial support for their contribution 
585 (Miller et al., 2011), but that land trusts also expect some level of sacrifice from landowners 586 (Keske, 2008).

587 One limitation of this analysis is that the results do not reflect the degree to which 588 landowners or land trusts actually sacrifice financial benefits to keep their lands in CE. Another 589 limitation is that welfare estimates could not be generated due to a high non-response rate among 590 land trust respondents (39.5\%) regarding land values. Given actual point estimates for land 591 values could not be calculated for many land trust respondents, only ordinal weightings 592 associated with price are elicited from both the models. However, landowner sacrifice is well593 documented in the literature and the significant, positive finding of the community attachment 594 and ecosystem services variables may be indicating landowners' commitment to provision of 595 amenities to their communities. Our results offer some evidence that landowners with more agricultural sales and or off 597 farm income potential are more likely to choose a CE and perhaps more willing to signal some 598 sacrifice to do so. This suggests respondents who have more income potential are more likely to 599 consider a CE. This may be related to cash rich and land rich landowners being more likely to 600 consider a $\mathrm{CE}$ than those who are cash poor, and it is related to previous findings suggesting 601 landowners with higher economic dependence were less likely to have an easement (Cross et al., 602 2011). These results suggest cash poor landowners are more likely to not choose a CE so they 603 can maintain the option value for added income from development of housing on their land.

604 Flexibility to choose what to do with the land in the future was expressed as a concern by 605 landowners in the focus groups (Miller et al., 2011). This suggests much higher benefit values 606 may need to be offered to entice landowners in this situation to consider a CE. 
Other variables seem to affect landowner choices. Consistent with conclusions from

McGaffin et al. (2012) model results indicate that Wyoming landowners were less likely to choose a CE. This supports the notion that institutions and tradeable tax permits (in Colorado) are important considerations for the CE market and policy makers. Landowners perceiving their land to be more productive had a negative relation to $\mathrm{CE}$ choice. This may represent a perceived opportunity cost associated with flexibility of using the land or less concern that productive land would be converted. Those landowners who lived in either Colorado or Wyoming longer were less likely to choose an easement. This is consistent with previous research (Brenner et al., 2013), and it may suggest longer term landowners are more resistant to changing the nature of their property rights.

Landowners indicating they would not consider placing CEs on their land were more likely to not choose an easement, and this was weighted relatively high in that choice. This indicates some landowners do not view CEs as a viable alternative for their land. Those respondents indicating they would trust land trusts to manage the lands under CE were less likely to choose neither. This is consistent with previous research suggesting trust and more frequent visits by easement holders positively impacted landowner satisfaction with easements (Rissman and Sayre, 2012). However, the majority (71\%) of landowners did not indicate they trusted land trusts in our sample. Given the impact of this variable on probability of choice, this suggests distrust of land trusts could be an important barrier to CE transactions. If the landowner already had a CE in place, they were less likely to choose "neither", indicating that landowners having some experience with CEs were more likely to consider other CEs on their land.

If land trust agents perceived that lands in their area with CE potential were considered under growth pressure, respondents were less likely to choose a CE scenario. This could be 
630 related to concerns regarding potential opportunity costs to obtain the easement on the land or 631 having such lands in their current portfolio. Land trust agents with graduate education were 632 more likely to choose easements.

633 Overall, our results indicate potential issues related to differences between landowners 634 and land trusts that may lead to less successful CE negotiations. Sticking points seem to be 635 managerial control, public access, and distrust of land trusts in general. Land trusts may attract 636 more interest in CE transactions by making their priorities and CE attribute preferences known to 637 landowners. Concerns about heterogeneous (or unclear) land trust conservation priorities were 638 articulated within the landowner focus groups. Landowner trust of land trusts is clearly an issue 639 for respondents as indicated in the landowner model. Conversely, landowners who indicated 640 they already had a CE or trusted land trusts were more likely to choose CEs. Moreover, concern 641 that public access is required by many land trusts could be negatively influencing landowners' 642 willingness to consider conservation easements. Yet our results indicate this may be less of an 643 issue for many land trusts than landowners might think. These results point to potential 644 information asymmetry issues for landowners with little CE experience compared to land trust 645 agents. Land trusts need to better articulate their conservation priorities and community 646 attachment to landowners, so that landowners can more easily identify an organization with 647 similar values. This would likely reduce search costs for landowners seeking an easement 648 transaction. However, before engaging in a communication campaign, it may be worthwhile for 649 trusts to ensure that they are clear, internally, on their conservation priorities to avoid 650 exacerbating potential trust issues. Moreover, they need to be consistent with their actions 651 regarding their priorities. This may be even more important when approaching landowners in 652 areas with less history, information and institutions regarding easements. 
654 more easily identify landowners who share the same conservation priorities as a way to address

655 potential adverse selection problems. For example, focus group results indicated that landowners

656 acknowledged land trust interest in entering into CEs for wildlife protection (Miller et al., 2011).

657 The focus groups indicated that landowners were also interested in protecting wildlife, but that

658 they didn't necessarily need a CE in place in order to do so. These results were somewhat

659 validated in our quantitative results. Land trusts whose interest is in wildlife habitat protection

660 may benefit from creating a screening tool to identify landowners with similar motivations, or

661 whose land is conducive to achieving this conservation priority.

662

These results suggest that opportunities for reduction in search and transactions costs

663 among demanders and suppliers, improvement in CE acceptance, and increased transaction

664 frequency may hinge on education related to CE opportunities available to landowners from land

665 trusts. Land trusts need to be aware of concerns related to issues such as managerial control,

666 public access, lack of trust, and financial compensation when negotiating with landowners.

667 Moreover, heterogeneity amongst participants regarding these issues suggests some landowners

668 may be more or less concerned about these issues. Overall, these results indicate the need for

669 addressing potential information asymmetries between landowners and land trusts. Education

670 and information aimed at reducing assymetries should reduce matching costs associated with

671 finding the right land trust and the right parcel. Our research suggests understanding and

672 addressing the issues found could provide improvements in this emerging environmental market

673 and ultimately improve sustainable land use and agricultural landscapes conservation.

674 Despite the contribution of this article and the growing body of literature regarding

675 conservation easements, issues requiring further investigation remain. Understanding the 
676 economic value or welfare associated with landowner decisions to enter into conservation

677 easements would provide important information about benefits received as well as what may be

678 needed to attract additional CE transactions. While our results, and of others, indicates distrust

679 of land trusts is a barrier, relatively little is known about the root causes and potential remedies to

680 address this problem. Overall, the literature regarding landowner motivations seems to be more

681 complete than for land trusts. Further research understanding motivations and issues for land

682 trusts could enhance the body of knowledge as well the functioning of this evolving market. 


\section{References}

Anderson, K., \& Weinhold, D. (2008). Valuing future development rights: the costs of conservation easements. Ecological Economics, 68(2), 437-446. doi10.1016/j.ecolecon.2008.04.015

Bergstrom, J. C., Dillman, B. L. \& Stoll, J. R. (1985). Public environmental amenity benefits of private land: the case of prime agricultural land. Southern Journal of Agricultural Economics, 17, 139-149.

Bode, M., Probert, W., Turner, W. R., Wilson, K. A., \& Venter, O. (2011) Conservation planning with multiple organizations and objectives. Conservation Biology, 25(2), 295-304. doi $-10.1111 / \mathrm{j} .1523-1739.2010 .01610 . \mathrm{x}$

Boykin, J. H., \& McLaughlin, J.A. (2006). Addressing enhancement in conservation easement appraisals. The Appraisal Journal, 74(3), 239-249.

Brain, R. G., Hostetler, M. E., \& Irani, T. A. (2014). Why do cattle ranchers participate in conservation easement agreements? Key motivators in decision making. Agroecology and Sustainable Food Systems, 38(3), 299-316. http://dx.doi.org/10.1080/21683565.2013.819479

Brenner, J. C., Lavallato, S., Cherry, M., \& Hileman, E. (2013). Land use determines interest in conservation easements among private landowners. Land Use Policy, 35(1), 24-32. http://dx.doi.org/10.1016/j.landusepol.2013.03.006

Chang, K. (2011). 2010 National Land Trust Census Report. Land Trust Alliance, Washington, D.C. Retrieved from https://www.landtrustalliance.org/land-trusts/land-trustcensus 
Cropper, E. D., McLeod, D. M., Bastian, C. T., Keske, C. M., Hoag, D. L., \& Cross, J. E. (2012). Factors affecting land trust agents' preferences for conservation easements. Journal of Regional Analysis and Policy, 42(2), 88-103.

Cross, J. E., Keske, C. M., Lacy, M. G., Hoag, D. L., \& Bastian, C. T. (2011). Adoption of conservation easements among agricultural landowners in Colorado and Wyoming: the role of economic dependence and sense of place. Landscape and Urban Planning, 101, 75-83. doi10.1016/j.landurbanplan.2011.01.005

Daniels, R., and Hensher, D. A. (2000). Valuation of environmental impacts to transportation projects: the challenge of self-interest proximity, Journal of Transport Economics and Policy, 34(2), 189-214.

Davidson, J. \& Weersink, A. (1998). What does it take for a market to function? Review of Agricultural Economics, 20(2), 558-572.

Day, B., Bateman, I. J., Carson, R. T., Dupont, D., Louviere, J. J., Morimoto, S., Scarpa, R., \& Wang, P. (2012). Ordering effects and choice set awareness in repeat-response stated preference studies. Journal of Environmental Economics and Management, 63, 73-91. doi:10.1006/j.jeem.2011.09.001

DeShazo, J. E., \& Fermo, G. (2002). “Designing choice sets for stated preference methods: the effects of complexity on choice consistency. Journal of Environmental Economics and Management, 44, 123-143. doi:10.1006/jeem.2001.1199

Dillman, D. A. (2000). Mail and web-based survey: the tailored design method. John Wiley \& Sons, New York. 
Domencich, T., and McFadden, D. (1975). Urban travel demand: a behavioural approach. North-Holland, Amsterdam.

Duke, J. M., Dundas, S. J., \& Messer, K. D. (2013) Cost-effective conservation planning: lessons from economics. Journal of Environmental Management, 125, 126-133. http://dx.doi.org/10.1016/j.jenvman.2013.03.048

Duke, J. M., \& Lynch, L. (2006). Farmland retention techniques: property rights implications and comparative evaluation. Land Economics, 82(2), 189-213.

Moss, C. B., \& Schmitz, A. (2014). Environmental flows from alternate land uses in the delta, pacific, and the southeastern states: 1947 - 2007. Journal of Environmental Protection, 5, 1531-1540. http://dx.doi.org/10.4236/jep.2014.516145

Farmer, J. R., Knapp, D., Meretsky, V. J., Chancellor, C., \& Fischer, B. C. (2011). Motivations influencing the adoption of conservation easements. Conservation Biology, 25(4), 827-834. doi - 10.1111/j.1523-1739.2011.01686.x

Farmer, J. R., Chancellor, C., \& Fischer, B. C. (2011). Motivations for using conservation easements as a land protection mechanism: a mixed methods analysis. Natural Areas Journal, 31(1), 80-87. http://dx.doi.org/10.3375/043.031.0109

Farmer, J. R., Meretsky, V., Knapp, D., Chancellor, C., \& Fischer, B. C. (2015). Why agree to a conservation easement? Understanding the decision of conservation easement granting. Landscape and Urban Planning, 138(1), 11-19. http://dx.doi.org/10.1016/j.landurbplan.2015.01.005 
Geoghegan, J., Lynch, L., \& Bucholtz, S. (2003). Capitalization of open spaces: can agricultural easements pay for themselves? Agricultural and Resource Economics Review, 32(1), 33-45.

Gerber, J. D., \& Rissman, A. R. (2012). Land-conservation strategies: The dynamic relationship between acquisition and land-use planning. Environment and Planning-Part A, 44(8), 1836-1855. doi - 10.1068/a44395

Greene, R. P., \& Stager, J. (2002). Rangeland to cropland conversions as replacement land for prime farmland lost to urban development. The Social Science Journal, 38(4), 543-555.

Gustanski, J. A., \& Squires, R. H. (2000). Protecting the land: conservation easements past, present and future. Island Press, Washington, D.C.

Hensher, D., \& Greene, W. H. (2003). The mixed logit model: the state of practice. Transportation, 30, 133-176.

Hummon, D. M. (1992). In Altman, I., and S. Low (Eds.), Community attachment: local sentiment and sense of place. pp. 253-278. Plenum, New York.

Inman, K., \& McLeod, D. M. (2002). Property rights and public interests: a Wyoming agricultural lands study. Growth and Change, 33(1), 91-114.

Inman, K., McLeod, D. M., \& Menkhaus, D. J. (2002). Rural land use and sale preferences in a Wyoming county. Land Economics, 78(1), 72-87.

Jorgensen, B. S., \& Stedman R. C. (2001). Sense of place as an attitude: lakeshore owners' attitudes toward their properties. Journal of Environmental Psychology, 21(3), 233-248. doi $-10.1006 /$ jevp.2001.0226 
Kabii, T., \& Horwitz, P. (2006). A review of landholder motivations and determinants for participation in conservation covenanting programmes. Environmental Conservation, 33(1), 1120. doi $-10.1017 / \mathrm{s} 0376892906002761$

Keske, C. M. (2008). The emerging market for private land preservation and conservation easements: rents, efficiency, and incomplete markets. Verlag Dr. Muller Aktiengesellschaft \& Company Publishers, Saarbrucken, Germany.

Keske, C. M., Hoag, D.L., \& Bastian, C. T. (2009). Can the market for conservation easements evolve from emerging to efficient? Western Economics Forum, 8(1), 7-17.

Keske, C. M., Bastian, C. T., McLeod, D. M., Hoag, D. L., \& Lacy, M. G. (2011). Using mixed methods research in environmental economics: the case of conservation easements. International Journal of Mixed Methods in Applied Business and Policy Research, 1(1), 16-28.

Kuhfeld, W. F., Tobias, R. D., \& Garratt, M. (1994). Efficient experimental design with marketing research. Journal of Marketing Research, 31(4), 545-557.

Land Trust Alliance. Frequently Asked Questions. http://www.landtrustalliance.org/conservation/landowners/faqs-1/faq-land-trusts. Retrieved May 2,2015 .

Lerner J., Mackey, J., \& Casey, F. (2007). What's in Noah's wallet? Land conservation spending in the United States. BioScience, 57(5), 419-423.

Liberknect, K. (2009). Public access to U. S. conservation land trust properties. Journal of the American Planning Association, 75(4), 479-491. DOI 10.1080/01944360903212087 
Louviere, J. J., Hensher, D. A. \& Swait, J. D. (2000). Stated choice methods: analysis and application. Cambridge University Press, Cambridge.

Lubowski, R. N., Plantinga, A. J., \& Stavins, R. N. (2008). What drives land-use change in the United States? A national analysis of landowner decisions. Land Economics, 84(4), 529550.

Lynch, L., \& Lovell, S. J. (2003). Combining spatial and survey data to explain participation in agricultural land preservation programs. Land Economics, 79(2), 259-276.

Magnan, N., Seidl, A. F., \& Loomis, J. B. (2012). Is resident valuation of ranch open space robust in a growing rural community? Evidence from the Rocky Mountains. Society and Natural Resources, 25(9), 852-867. doi - 10.180/08941920.2011.642459

McFadden, D. (1976). The revealed preferences of a government bureaucracy: empirical evidence. Bell Journal of Economics, 7(1), 55-72.

McGaffin, G., McLeod, D., Bastian, C., Hoag, C., \& Hoag, D. (2012). Landowner preferences for conservation easements: responses from two intermountain states. Journal of the American Society of Farm Managers and Rural Appraisers, 75(10), 98-111.

Merenlender, A. M., Huntsinger, L., Guthey, G., \& Fairfax, S. K. (2004). Land trusts and conservation easements: Who is conserving what for whom? Conservation Biology, 18(1), 6576.

Milder, J. C., Lassoie, J. P., \& Bedford, B. L. (2008). Conserving biodiversity and ecosystem function through limited development: an empirical evaluation. Conservation Biology, 22(1), 70-79. 
Milder, J. C., \& Clark, S. (2011). Conservation development practices, extent, and landuse effects in the United States. Conservation Biology, 25(4), 697-707. doi - 10.1111/j.15231739.2011.01688.x

Miller, A. D. (2007). Factors affecting agricultural landowners' preferences for conservation easements and conserving amenities, M.S. Thesis, University of Wyoming, Laramie.

Miller, A. D., Bastian, C. T., McLeod, D. M., Keske, C. M., \& Hoag, D. L. (2011). Factors impacting agricultural landowners' willingness to enter into conservation easements: a case study. Society and Natural Resources, 24(1), 65-74.

http://dx.doi.org/10.180/08941920802684146

Polasky, S., Johnson, K., Keeler, B., Kovacs, K., Nelson, E., Pennington, D., Plantinga, A. \& Withey, J. (2012). Are investments to promote biodiversity conservation and ecosystem services aligned? Oxford Review of Economic Policy, 28(1), 139-163. doi10.1093/oxrep/grs011

Rissman, A., \& Sayre, N.F. (2012). Conservation outcomes and social relations: a comparative study of private ranchland conservation easements. Society and Natural Resources, 25(6), 523-538. http://dx.doi.org/10.180/08941920.2011.580419

Rissman, A. R., Lozier, L., Comendant, T.. Karevia, P., Kiesecker, J. M., Shaw, M. R., \& Merenlender, A. M. (2007). Conservation easements: biodiversity protection and private use. Conservation Biology, 21(3), 709-718. 
Rissman, A. R. (2010). Designing perpetual conservation agreements for land management. Rangeland Ecology and Management, 63(2), 167-175.

DOI:http://dx.doi.org/10.2111/08-251.1

SAS Institute Inc. (1990). SAS, 6th Edition. Cary, North Carolina.

Stroman, D. A., \& Kreuter, U. P. (2014). Perpetual conservation easements and landowners: Evaluating easement knowledge, satisfaction and partner organization relationships. Journal of Environmental Management, 146, 284-291.

http://dx.doi.org/10.1016/j.jenvman.2014.08.007

Sorice, M. G., Oh, C. O., Gartner, T., Snieckus, M., Johnson, R., \& Donlan, C. J. (2013). Increasing participation in incentive programs for biodiversity conservation. Ecological Applications, 23(5), 1146-1155.

Thurstone, L. L. (1927). A law of comparative judgement. Psychological Review, 34, 273-286. 
List of Tables

Table 1. Descriptive statistics of explanatory variables for the landowner model.

Table 2. Descriptive statistics of explanatory variables for the land trust agent model.

Table 3. Estimated landowner and land trust agent models with marginal effects.

List of Figures

Figure 1. Example of stated choice scenario attributes and levels. 
Table 1. Descriptive statistics of explanatory variables for the landowner model.

\begin{tabular}{|c|c|c|c|}
\hline Variable & Indirect utility equation for neither choice & $\begin{array}{c}\text { Mean } \\
\text { (Std. dev.) }\end{array}$ & $\begin{array}{l}\text { Expected } \\
\text { sign }\end{array}$ \\
\hline Variable & Description & $\begin{array}{l}\text { Mean } \\
\text { (Std. } \\
\text { dev.) }\end{array}$ & $\begin{array}{l}\text { Expected } \\
\text { sign }\end{array}$ \\
\hline $\begin{array}{l}\text { EASEMENT } \\
\text { LENGTH }\end{array}$ & $\begin{array}{l}\text { Perpetuity- }(0) \text { or } \\
20-25 \text { years }-(1)\end{array}$ & $\begin{array}{r}0.5582^{\mathrm{a}} \\
(0.4966)\end{array}$ & $\stackrel{+}{\mathrm{F}, \mathrm{L}^{\mathrm{b}}}$ \\
\hline $\begin{array}{l}\text { PUBLIC } \\
\text { ACCESS }\end{array}$ & Public access required. No $-(0)$ or Yes $-(1)$ & $\begin{array}{c}0.4809 \\
(0.4997)\end{array}$ & $\begin{array}{c}- \\
F, L\end{array}$ \\
\hline $\begin{array}{l}\text { WILDLIFE } \\
\text { HABITAT }\end{array}$ & $\begin{array}{l}\text { Habitat included under easement. } \\
\text { No- }-(0) \text { or Yes }-(1)\end{array}$ & $\begin{array}{c}0.4986 \\
(0.5000)\end{array}$ & $\begin{array}{c}+ \\
\mathrm{F}, \mathrm{L}\end{array}$ \\
\hline CONTROL & $\begin{array}{l}\text { Restricted managerial control of landowner. } \\
\text { No }-(0) \text { or Yes - (1) }\end{array}$ & $\begin{array}{c}0.5220 \\
(0.4996)\end{array}$ & - \\
\hline BENEFIT & $\begin{array}{l}\text { Varied between } 0,25,50,75 \text {, or } 100 \% \text { of the } \\
\text { property's average market value. Landowner's } \\
\text { estimate of average market value per acre asked } \\
\text { prior to stated choice question. Scenarios listed } \\
\text { as being in perpetuity were listed as being } \\
\text { eligible for potential income or estate tax } \\
\text { benefits. Those not in perpetuity did not } \\
\text { indicate this potential benefit. }\end{array}$ & $\begin{array}{l}51.2079 \\
(36.0219)\end{array}$ & $\stackrel{+}{\mathrm{F}, \mathrm{E}, \mathrm{L}}$ \\
\hline STATE & $\begin{array}{c}\text { Landowner state of residence - Colorado (0) or } \\
\text { Wyoming (1) }\end{array}$ & $\begin{array}{c}0.2520 \\
(0.4342)\end{array}$ & $\bar{L}$ \\
\hline PRODUCTIVITY & $\begin{array}{l}\text { Landowner's agreement with statement } \\
\text { "productive capacity of my land is excellent for } \\
\text { this area" with Likert scale response ranging } \\
\text { from strongly disagree (1) to strongly agree (5). }\end{array}$ & $\begin{array}{c}3.6121 \\
(1.0500)\end{array}$ & $\bar{L}$ \\
\hline ECOSYSTEM & $\begin{array}{l}\text { Summated Likert scale from eight questions } \\
\text { regarding provision of habitat and ecosystem } \\
\text { services provided by the respondent's lands. } \\
\text { (range } 8 \text { to } 40 \text { ) }\end{array}$ & $\begin{array}{l}26.6778 \\
(6.9906)\end{array}$ & $\stackrel{+}{\mathrm{F}, \mathrm{L}}$ \\
\hline COMMUNITY & $\begin{array}{l}\text { Summated Likert scale from twenty questions } \\
\text { regarding dimensions of community attachment } \\
\text { or sense of place. (range } 20 \text { to } 100 \text { ) }\end{array}$ & $\begin{array}{l}77.1396 \\
(12.8366)\end{array}$ & $\stackrel{+}{\mathrm{F}, \mathrm{L}}$ \\
\hline
\end{tabular}




\begin{tabular}{|c|c|c|c|}
\hline YEARS & $\begin{array}{l}\text { The number of years the respondent had lived in } \\
\text { Wyoming or Colorado (0 to } 93)\end{array}$ & $\begin{array}{c}50.1952 \\
(18.9743)\end{array}$ & $?$ \\
\hline COLLEGE & $\begin{array}{l}1 \text { to } 4 \text { years of college after high school - No (0) or } \\
\text { Yes (1) }\end{array}$ & $\begin{array}{c}0.4513 \\
(0.4976)\end{array}$ & $\overline{\mathrm{L}}$ \\
\hline VOTECH & $\begin{array}{l}\text { Vocational or Technical education after high school } \\
- \text { No (0) or Yes (1) }\end{array}$ & $\begin{array}{c}0.0993 \\
(0.2991)\end{array}$ & $?$ \\
\hline GRADUATE & $\begin{array}{l}\text { At least some graduate school education }- \text { No }(0) \text { or } \\
\text { Yes (1) }\end{array}$ & $\begin{array}{c}0.1817 \\
(0.3856)\end{array}$ & $\overline{\mathrm{L}}$ \\
\hline AG SALES & $\begin{array}{l}\text { Last year's annual ag sales (based on ag census } \\
\text { ranges ranging from less than } \$ 1000 \text { to over } \\
\$ 500,000 \text { ) coded as midpoint of category }\end{array}$ & $\begin{array}{c}84780.99 \\
(131726.10)\end{array}$ & $\begin{array}{l}+ \\
\mathrm{L}\end{array}$ \\
\hline OFF FARM & Respondent employed off farm - No (0) or Yes (1) & $\begin{array}{c}0.4403 \\
(0.4964)\end{array}$ & $\begin{array}{l}+ \\
\mathrm{L}\end{array}$ \\
\hline $\begin{array}{l}\text { EASEMENT } \\
\text { EVER }\end{array}$ & $\begin{array}{c}\text { Respondent would not consider putting a } \\
\text { conservation easement on their property - No (0) or } \\
\text { Yes (1) }\end{array}$ & $\begin{array}{c}0.4496 \\
(0.4975)\end{array}$ & $\begin{array}{l}+ \\
\mathrm{F}\end{array}$ \\
\hline TRUST & $\begin{array}{l}\text { Respondent trusts land trusts to protect their interest } \\
\text { if they hold easement on their property - No (0) or } \\
\text { Yes (1) }\end{array}$ & $\begin{array}{c}0.2862 \\
(0.4520)\end{array}$ & $\overline{\mathrm{F}}$ \\
\hline $\begin{array}{c}\text { CURRENTLY } \\
\text { CE }\end{array}$ & $\begin{array}{c}\text { Respondent currently has a conservation easement } \\
\text { on a parcel of land they own or manage - No (0) or } \\
\text { Yes (1) }\end{array}$ & $\begin{array}{c}0.1051 \\
(0.3067)\end{array}$ & $\overline{\mathrm{F}}$ \\
\hline
\end{tabular}

Table 1. Descriptive statistics of explanatory variables for the landowner model (continued).

${ }^{a}$ Means for categorical variables were calculated as simple averages across observations used to estimate the model. For easement attributes, means near 0.5 for those variables with only 2 levels are expected indicating that about half the respondents received 1 of 2 potential attribute levels. The midpoint level for the price variable is near 50, again indicating approximately equal distribution of the levels across respondents in the stated choice design.

${ }^{b}$ Expected sign of variable in model based on expectations from focus group findings $(\mathrm{F})$, existing literature $(\mathrm{L})$, economic theory $(\mathrm{E})$. 
Table 2. Descriptive statistics of explanatory variables for the land trust agent model.

\begin{tabular}{|c|c|c|c|}
\hline Variable & Description & $\begin{array}{c}\text { Mean } \\
\text { (Std. dev.) }\end{array}$ & $\begin{array}{c}\text { Expected } \\
\text { sign }\end{array}$ \\
\hline $\begin{array}{l}\text { EASEMENT } \\
\text { LENGTH }\end{array}$ & Perpetuity- $(0)$ or $20-25$ years $-(1)$ & $\begin{array}{l}0.5535^{\mathrm{a}} \\
(0.4972)\end{array}$ & $\overline{F,} L^{b}$ \\
\hline $\begin{array}{l}\text { PUBLIC } \\
\text { ACCESS }\end{array}$ & Public access required. No $-(0)$ or Yes $-(1)$ & $\begin{array}{c}0.4842 \\
(0.4999)\end{array}$ & $\stackrel{+}{\mathrm{F}, \mathrm{L}}$ \\
\hline $\begin{array}{l}\text { WILDLIFE } \\
\text { HABITAT }\end{array}$ & $\begin{array}{l}\text { Habitat included under easement. } \\
\text { No }-(0) \text { or Yes }-(1)\end{array}$ & $\begin{array}{c}0.4967 \\
(0.5001)\end{array}$ & $\stackrel{+}{\mathrm{F}, \mathrm{L}}$ \\
\hline CONTROL & $\begin{array}{l}\text { Restricted managerial control of landowner. } \\
\text { No }-(0) \text { or Yes }-(1)\end{array}$ & $\begin{array}{c}0.5353 \\
(0.4989)\end{array}$ & $\begin{array}{l}+ \\
F\end{array}$ \\
\hline BENEFIT & $\begin{array}{l}\text { Varied between } 0,25,50,75 \text {, or } 100 \% \text { of the } \\
\text { property's average market value. Land trust } \\
\text { agent's estimate of average market value per acre } \\
\text { in the area asked prior to stated choice question. } \\
\text { Scenarios listed as being in perpetuity were listed } \\
\text { as being eligible for potential income or estate } \\
\text { tax benefits. Those not in perpetuity did not } \\
\text { indicate this potential benefit. }\end{array}$ & $\begin{array}{c}50.1163 \\
(35.8778)\end{array}$ & F, E \\
\hline COMMUNITY & $\begin{array}{c}\text { Summated Likert scale from nine questions } \\
\text { regarding various dimensions of community or } \\
\text { place attachment worded similarly to landowner } \\
\text { questions. ( } 9 \text { to } 45 \text { ) }\end{array}$ & $\begin{array}{l}38.3117 \\
(4.7663)\end{array}$ & $\stackrel{+}{\mathrm{F}, \mathrm{L}}$ \\
\hline ECOSYSTEM & $\begin{array}{c}\text { Summated Likert scale regarding land trust level } \\
\text { of ecosystem preservation focus from four } \\
\text { questions. ( } 4 \text { to } 20)\end{array}$ & $\begin{array}{l}15.5888 \\
(2.6984)\end{array}$ & $\begin{array}{c}+ \\
\mathrm{F}, \mathrm{L}\end{array}$ \\
\hline $\begin{array}{l}\text { GROWTH } \\
\text { PRESSURE }\end{array}$ & $\begin{array}{l}\text { Summated Likert scale regarding growth } \\
\text { pressure where land trust wishes to protect land } \\
\text { from five questions. ( } 5 \text { to } 25 \text { ) }\end{array}$ & $\begin{array}{l}18.3262 \\
(2.9740)\end{array}$ & $\begin{array}{c}+ \\
\mathrm{F}, \mathrm{L}\end{array}$ \\
\hline $\begin{array}{c}\text { ECONOMIC } \\
\text { ATTACHMENT }\end{array}$ & $\begin{array}{l}\text { Summated Likert scale regarding land trust } \\
\text { agent's view of landowners as economically } \\
\text { attached to their lands from three questions. ( } 3 \text { to } \\
15 \text { ) }\end{array}$ & $\begin{array}{c}9.6962 \\
(2.3472)\end{array}$ & $\overline{F, L}$ \\
\hline
\end{tabular}


Table 2. Descriptive statistics of explanatory variables for the land trust agent model (continued).

\begin{tabular}{|c|c|c|c|}
\hline Variable & $\begin{array}{l}\text { Indirect utility equation for } \\
\text { neither choice }\end{array}$ & $\begin{array}{c}\text { Mean } \\
\text { (Std. dev.) }\end{array}$ & $\begin{array}{l}\text { Expected } \\
\text { sign }\end{array}$ \\
\hline HOLD & Does your organization currently hold & 0.9268 &  \\
\hline EASEMENTS & conservation easements? No (0) or Yes (1) & $(0.2605)$ & $\mathrm{F}, \mathrm{L}$ \\
\hline BUDGET & $\begin{array}{l}\text { Operating budget of land trust. Ranging } 50,000 \text { to } \\
\qquad \$ 5,750,000 \\
\text { at midpoints of categories. }\end{array}$ & $\begin{array}{c}881503.2 \\
(1457490)\end{array}$ & $\bar{F}$ \\
\hline GRADUATE & $\begin{array}{c}\text { At least some graduate school education - No (0) } \\
\text { or Yes (1) }\end{array}$ & $\begin{array}{c}0.6887 \\
(0.4631)\end{array}$ & + \\
\hline VOTECH & $\begin{array}{l}\text { Vocational or Technical education after high } \\
\text { school - No (0) or Yes (1) }\end{array}$ & $\begin{array}{l}0.0113 \\
(0.1058)\end{array}$ & $?$ \\
\hline YEARS & $\begin{array}{c}\text { How many years have you lived in your current } \\
\text { state of residence? }\end{array}$ & $\begin{array}{c}25.6670 \\
(18.8563)\end{array}$ & $?$ \\
\hline
\end{tabular}

\footnotetext{
${ }^{\mathrm{a}}$ Means for categorical variables were calculated as simple averages across observations used to estimate the model. For easement attributes, means near 0.5 for those variables with only 2 levels are expected indicating that about half the respondents received 1 of 2 potential attribute levels. The midpoint level for the price variable is near 50, again indicating approximately equal distribution of the levels across respondents in the stated choice design.

${ }^{\mathrm{b}}$ Expected sign of variable in model based on expectations from focus group findings $(\mathrm{F})$, existing literature $(\mathrm{L})$, economic theory $(\mathrm{E})$.
} 
Table 3. Estimated landowner and land trust agent models with marginal effects.

\begin{tabular}{|c|c|c|c|c|c|}
\hline Variable & $\begin{array}{l}\text { Parameter } \\
\text { Estimate }\end{array}$ & $\begin{array}{c}\text { Marginal } \\
\text { Effect }^{a}\end{array}$ & Variable & $\begin{array}{l}\text { Parameter } \\
\text { Estimate }\end{array}$ & $\begin{array}{c}\text { Marginal } \\
\text { Effect }\end{array}$ \\
\hline \multicolumn{6}{|c|}{ Indirect utility equations for easement choice } \\
\hline \multicolumn{2}{|c|}{ Landowner model } & \multicolumn{4}{|c|}{ Land trust model } \\
\hline $\begin{array}{l}\text { EASEMENT } \\
\text { LENGTH }\end{array}$ & $\begin{array}{l}-1.0047 * * * \\
(1.9843)^{* * *} \mathrm{c}\end{array}$ & 0.0123 & $\begin{array}{l}\text { EASEMENT } \\
\text { LENGTH }\end{array}$ & $\begin{array}{c}-2.0194 * * * \\
(0.0005)\end{array}$ & -0.1460 \\
\hline $\begin{array}{l}\text { PUBLIC } \\
\text { ACCESS }\end{array}$ & $\begin{array}{l}-1.6080^{* * *} \\
(1.5593) * * *\end{array}$ & -0.0183 & $\begin{array}{l}\text { PUBLIC } \\
\text { ACCESS }\end{array}$ & -0.2063 & -0.0141 \\
\hline $\begin{array}{l}\text { WILDLIFE } \\
\text { HABITAT }\end{array}$ & 0.0520 & 0.0024 & $\begin{array}{l}\text { WILDLIFE } \\
\text { HABITAT }\end{array}$ & $\begin{array}{c}1.4702 * * * \\
(0.1532)\end{array}$ & 0.1335 \\
\hline CONTROL & -0.1767 & -0.0080 & CONTROL & $\begin{array}{c}0.5440 * * * \\
(0.0737)\end{array}$ & 0.0472 \\
\hline BENEFIT & $\begin{array}{c}0.0131 * * * \\
(.00754)\end{array}$ & 0.0733 & BENEFIT & $\begin{array}{c}-0.0047 * * \\
(0.0091)\end{array}$ & -0.0320 \\
\hline STATE & $-0.3696 * * *$ & -0.0072 & $\begin{array}{l}\text { GROWTH } \\
\text { PRESSURE }\end{array}$ & $-0.0832 * *$ & -0.2355 \\
\hline PRODUCTIVITY & $-0.1273 * *$ & -0.0412 & $\begin{array}{c}\text { ECONOMIC } \\
\text { ATTACHMENT }\end{array}$ & -0.0430 & -0.0639 \\
\hline ECOSYSTEM & $0.0184^{*}$ & 0.0450 & ECOSYSTEM & 0.0126 & 0.0305 \\
\hline COMMUNITY & $0.0242 * * *$ & 0.1702 & COMMUNITY & $0.0452 *$ & 0.2691 \\
\hline \multicolumn{6}{|c|}{ Indirect utility equation for neither choice } \\
\hline CONSTANT & $3.3683 * * *$ & & CONSTANT & -0.1077 & \\
\hline YEARS & $0.0120 * * *$ & 0.0733 & YEARS & 0.0037 & 0.0061 \\
\hline COLLEGE & 0.0717 & 0.0040 & $\begin{array}{c}\text { HOLD } \\
\text { EASEMENTS }\end{array}$ & 0.0390 & 0.0162 \\
\hline VOTECH & 0.2732 & 0.0034 & VOTECH & 0.1434 & 0.0005 \\
\hline GRADUATE & -0.2848 & -0.073 & GRADUATE $^{\mathrm{b}}$ & $-0.4595^{* *}$ & -0.0524 \\
\hline AG SALES & $-0.143-05^{* * *}$ & -0.0165 & BUDGET & 0.0000 & 0.0000 \\
\hline OFF FARM & $-0.4538 * * *$ & -0.0281 & --- & --- & ---- \\
\hline EASEMENT EVER & $1.3596 * * *$ & 0.0605 & ---- & ---- & --- \\
\hline
\end{tabular}




\begin{tabular}{|c|c|c|c|c|c|}
\hline TRUST & $-1.6931 * * *$ & -0.0789 & ---- & ---- & ---- \\
\hline CURRENTLY CE & $-0.6080 * *$ & -0.0089 & ---- & ---- & ---- \\
\hline Log Likelihood & -1991.322 & & & -609.140 & \\
\hline Pseudo-R ${ }^{2}$ & 0.364 & & & 0.235 & \\
\hline Chi-square & 2266.836 & & & 374.71 & \\
\hline $\mathrm{N}$ & 3684 & & & 1075 & \\
\hline
\end{tabular}

* Significant at $\alpha=.10 ; * *$ Significant at $\alpha=.05 ; * * *$ Significant at $\alpha=.01$

a Total direct effect elasticity is estimated as average over observations.

${ }^{\mathrm{b}}$ Correlation coefficient between College and Graduate education variables was very high for the land trust agents $>0.90$. Only Graduate education was included to address collinearity between these two variables in the land trust model.

${ }^{c}$ Estimated standard deviation of parameter reported (*.*). Signficant dispersion around parameter estimate, $* * *$ indicates alpha $=0.01$. Only those easement attribute variables that were statistically significant in the multinomial logit formulation were estimated as random parameters. 


\begin{tabular}{|c|c|c|c|}
\hline Features & $\begin{array}{c}\text { Easement } \\
\text { A }\end{array}$ & $\begin{array}{c}\text { Easement } \\
\text { B }\end{array}$ & Neither \\
\hline Contract Length of Easement & Perpetuity & Perpetuity & \multirow{5}{*}{$\begin{array}{l}\text { No conservation } \\
\text { easement is } \\
\text { granted. } \\
\text { Right to } \\
\text { develop fully } \\
\text { the land for } \\
\text { housing is } \\
\text { unaffected in } \\
\text { any way. }\end{array}$} \\
\hline Access Provided to the Public & Yes & No & \\
\hline $\begin{array}{l}\text { Habitat on the parcel would be } \\
\text { placed under protection from } \\
\text { development (e.g. wildlife) }\end{array}$ & Yes & No & \\
\hline $\begin{array}{c}\text { Alternative production practices } \\
\text { or enterprises must be approved } \\
\text { by the land trust before } \\
\text { implementation }\end{array}$ & Yes & No & \\
\hline $\begin{array}{l}\text { Payment for easement expressed } \\
\text { as a percent of the average land } \\
\text { market value (as expressed in } \\
\text { section B question 1) in addition } \\
\text { to any tax benefits }\end{array}$ & $\begin{array}{l}\text { Income and } \\
\text { estate tax } \\
\text { benefits plus } \\
50 \% \text { of average } \\
\text { market value of } \\
\text { land }\end{array}$ & $\begin{array}{l}\text { Income and } \\
\text { estate tax } \\
\text { benefits plus } \\
25 \% \text { of average } \\
\text { market value of } \\
\text { land }\end{array}$ & \\
\hline \multirow[t]{2}{*}{$\begin{array}{l}\text { Given the above attributes } \\
\text { which easement would you } \\
\text { prefer? }\end{array}$} & $\begin{array}{l}\mathbf{A} \\
\square\end{array}$ & $\begin{array}{l}\mathbf{B} \\
\square\end{array}$ & $\begin{array}{c}\text { I choose } \\
\text { Neither A Nor } \\
\text { B }\end{array}$ \\
\hline & & & $\square$ \\
\hline
\end{tabular}

Figure 1. Example of stated choice scenario attributes and levels. 